\title{
Drawing the Demarcation Line: An Analysis of Sexual Harassment in Selected Learning Institutions in Nueva Ecija, Philippines Using Blumer's Interactionism Model
}

\author{
Arneil G. Gabriel, Honorato P. Panahon \\ Department of Public Administration, Nueva Ecija University of Science and Technology, Cabanatuan City, Philippines \\ Email: opats14@yahoo.com
}

How to cite this paper: Gabriel, A.G. and Panahon, H.P. (2017) Drawing the Demarcation Line: An Analysis of Sexual Harassment in Selected Learning Institutions in Nueva Ecija, Philippines Using Blumer's Interactionism Model. Open Access Library Journal, 4: e3328.

http://dx.doi.org/10.4236/oalib.1103328

Received: December 23, 2016

Accepted: January 19, 2017

Published: January 22, 2017

Copyright $\odot 2017$ by authors and Open Access Library Inc.

This work is licensed under the Creative Commons Attribution International License (CC BY 4.0).

http://creativecommons.org/licenses/by/4.0/

\begin{abstract}
The study draws the line between sexual harassment act and socially acceptable behavior. Through symbolic interactionism and gender-power configuration theories, defining features of sexual harassment are drawn from the perspectives of 160 teacher education students-participants from four universities in Nueva Ecija, Philippines. The socio-psychological, legal and lay approaches to the study of sexual harassment guide the data gathering. The findings revealed that there is no significant difference in the level of awareness of the group samples as evidenced by a computed $t$-value of 1.936 less than the tabulated $t$-value of 2.447. The study argued that legal approach to the study of sexual harassment is insufficient to prevent it. Thus, standard of behavior must be set within the demarcation line both by public and private learning institutions while intensified awareness campaign must be undertaken to ensure safe and conducive learning environment the students rightfully deserve.
\end{abstract}

\section{Subject Areas}

Education, Social Issues and Public Policy, Sociology

\section{Keywords}

Sexual Harassment, Teacher-Student Relationship, Case Study, Teacher Education, Theory of Interactionism

\section{Introduction}

\subsection{Definition of Sexual Harassment}

What is sexually harassing to one person may not be the same to another. The 
lack of universal and uniform socio-cultural interpretation of the phenomenon makes it more difficult to formulate accurate definition applicable to all cultures. According to McKinnon [1], it is an unwanted imposition of sexual requirements in the context of a relationship of unequal power. Accordingly, Katz defines sexual harassment as "one aspect of social sexual behavior characterized by repetitiveness, unwelcome, and in inherently coercive acts" [2]. Meanwhile, the American Equal Employment Opportunity Commission (EEOC) defines sexual harassment in the context of a workplace as an "unwelcome social advances, requests, for sexual favors and other verbal or physical conduct of a sexual nature constitute sexual harassment when this conduct explicitly or implicitly affects an individuals employment, unreasonably interferes with an individuals work performance or creates an intimidating hostile or offensive work environment" [3]. For the purpose of the study, sexual harassment is conceived as any behavior, arising from interaction, either verbal or non verbal, that brings sexual insinuation or insult upon another person regardless of gender and intention of the doer and the perceiver. On the other hand, socially acceptable behavior is defined as any act which approximately passes to the socio-cultural standard of the community as perceived by the individual target of such behavior. It is a behavior that does not cross the boundary line sets by the socio cultural orientation of the giver of meaning to interaction. The lack of universally applicable definition [4] and the multi disciplinary nature of sexual harassment made the issue difficult to combat. The socio-cultural differences in most jurisdictions affect the efficacy of borrowed foreign models and features of behavior considered as sexual harassment. Though, legal parameters, elements and circumstances for the commission are already set by law, the problem of interpretation as to what act falls under it remains dependent on the interaction between social psychological and cultural context. The study argued that the use of legal approach to solve the problem is inadequate. It is punitive rather than preventive. Thus appropriate intervention is necessary. There are two types of intervention; 1 ) the psychosocial and lay approaches where prevention is the main focus; and 2) legal approach where the end goal is to prosecute and punish violators.

\subsection{Background and Its Setting}

The trend in sexual harassment studies showed that prevalence of sexual harassment is a manifestation of power imbalance in society. It involves the improper use of perceived power. It is an issue better solve within the socio-psychological and cultural domains. It is also an issue to be explained by a social scientist rather than a lawyer whose treatment is unduly restricted by the legal definition and the limit of statutory construction. The multidisciplinary nature of sexual harassment makes it all the more difficult to understand and delineate the demarcation line between socially acceptable behavior and sexual harassment act [5]. The nature of sexual harassment as a gendered expression of power in society is apparent in a teacher-student relationship. According to Paludi [6] many students admire their teachers both in terms of wisdom and life achieve- 
ment. They look up to their teachers not only because of the authority to award academic grade but also the power to impose punishment. This relationship makes the students prone to extra ordinary sexual attention [7]. The academic and social admirations of students to their teacher create a perceived power configuration. At one end of the continuum is the powerful teacher and at the losing end are student-victims. This leaves the student with a choice either to establish deeper consensual sexual relationship with the teacher or unwillingly cooperate to the demand for sexual favor (quid pro quo harassment) in exchange for grades [8]. In both cases, the highest standard of ethics demanded of teaching as a noble profession is compromised [9].

In recent years, Higher Education Institutions (HEI) are challenged by the disturbing effects of social problems. The noble intention of learning institutions has been threatened by numerous issues blocking and sacrificing all its efforts to create a safe and secure learning environment. The problems on hazing activities and their impact on higher education students' career goals [10]; workplace bullying in secondary workplace setting [11] and sexual harassment [12] are just some of the problems tainting the reputation and good image of the academe.

The problem on sexual harassment transcends territorial boundaries and the knowledge on the nature, severity and perceptions of university students on harassment are essential to analyze the problem [5]. In one study, $67 \%$ of students in universities in Spain cannot recognize acts of sexual harassment behavior [13]. In America, the problem exists even in secondary level of education. Recent findings among secondary schools showed that $83 \%$ of girls and $60 \%$ of boys in 79 American institutions received unwanted sexual attention. Attention which ruins university student self-esteem, professional ambition, learning motivation, psychological health, physical well-being and vocational development [14]. In fact, in the survey made by the Association of American University Women (AAUW) among 1965 grades 7-12 showed that majority of the respondents revealed that once in their stay in school, they have experienced being harassed, have been witnesses to sexual harassment, and became harassers themselves [15].

The study "Drawing the Demarcation Line: An Analysis of Sexual Harassment in Selected Learning Institutions Using Blumer's Interactionism Model looks into sexual harassment as an attribute of interaction and the meaning the participants give to certain behaviors and tried to draw demarcation line between acceptable behavior and sexual harassment act.

\subsection{Anti Sexual Harassment Initiatives in the Philippines}

The signing of the Philippines in the Universal Declaration to protect women made the government perform an active role in terms of parliamentary and executive initiatives in relation to the protection of women. The United Nations Declaration for the Protection of Women binds the Philippines to observe the principle of Pacta Sun Servanda [16]. It is a norm of political conduct in Interna- 
tional Law imposing upon the Philippines the duty to protect women workers. Thus, international agreement on the protection of women metamorphosed into several domestic laws and policies. For instance, the 1987 Philippine Constitution declares the fundamental equality of men and women including "opportunities for work and work promotion" [17]. Further, the Labor Code of the Philippines [18] ensures that women workers are provided with friendly and conducive working environment adaptable to their gender needs. In general, the Philippine $16^{\text {th }}$ point development agenda, gender equality is made part and parcel of the priority development programs of the country [19]. Finally, a special law was created to protect women from abuse-RA 7877 or the Anti Sexual Harassment Act [20]. The aim is to eradicate or minimize sexual advances in the work place, learning institutions and training centers, committed by people having moral ascendancy over students, trainees, and employees.

Still, the government is perceived inefficient in the areas of dissemination, implementation and prosecution of offenses involving sexual harassment [21]. According to the Philippine Civil Service Commission, "Compliance of Higher Educational Institutions with RA 7877 showed that in 2011 alone, 42 complaints from State Universities and Colleges (SUCs) and 49 complaints from Private Higher Education Institutions (HEIs) were reported to CHED" [22]. But the data represent only the tip of an iceberg. Many are still unreported. The social stigma and inadequate knowledge of the procedures available to seek redress of their grievances are some of the known reasons cases of sexual harassment is not reported to proper authorities. According to Kintanar they are "discouraged to report because of the prevalence of double standard of morality existing in the Philippine society which sometimes converts the victim into the position of the accused serving the penalty of social rejection and ostracism" [23]. The same observation prevailed in other jurisdiction. According to Akthar [24] women victims tend to endure the effects of sexual harassment for the fear of double victimization. The persistence, prevalence and magnitude of the problem of sexual harassment despite numerous enacted policies to protect women's interests in society inspired the researcher to undertake this study. The study hopes, to contribute to the inadequate case studies and literature on the issue. The findings, though limited in application to cultural context, may also provide case specific guidelines on how professional teachers may readjust interactions with their students and prevent malicious accusation of sexual harassment.

The specific objectives of the study are as follows:

1) To describe the respondents personal attributes;

2) To describe the respondents interpretation of certain verbal, visual and physical behaviors.

3) To determine the demarcation line between sexual harassment and socially acceptable behaviors on the point of view of teacher education students;

4) To determine whether there is significant difference on the level of perception on sexual harassment among groups of university teacher education students. 


\section{Research Methods}

\subsection{Research Paradigm}

Figure 1 presents the research paradigm. It posits that sexual harassment as a social problem is affected by the interaction and the meaning that individuals give to their experiences [25]. The behavior and its meaning rest on a person's perception of the action/message and interpretation affecting the external world. The interaction between students and teacher can be the subject of research to identify characteristics of sexual harassment behaviors distinct and separate from socially accepted behavior. The process begins with the Junior and Senior Teacher education students as giver of meaning to actuations. The actions are perceived by the students in their day to day interaction with their teachers. The acts could be physical, social and visual behaviors. The symbolic representation of concept enters into the labeling process of the recipient students. In the labeling process, students give names or meaning to the perceived actions. Some of the factors affecting their labeling process are personal attributes of Junior and Senior Teacher Education students; the power relation between them and their teacher; and the environmental setting of the place where the action is taken. The third box is referred to as the defining features box. They consist of several relations and specific elements required to consider certain act as sexual harassment act. They are chiefly based on RA 7877. Some of the factors considered by the study are: age, gender, level of awareness, moral ascendancy, malicious intention, ability to grant rewards and impose penalty and personal relationship.

The fourth box argues that upon identifying the features, acts or behaviors are categorized as socially acceptable or sexual harassment. In the case of sexual harassment behavior (as interpreted by students), an agent of change is necessary to rectify wrong committed.

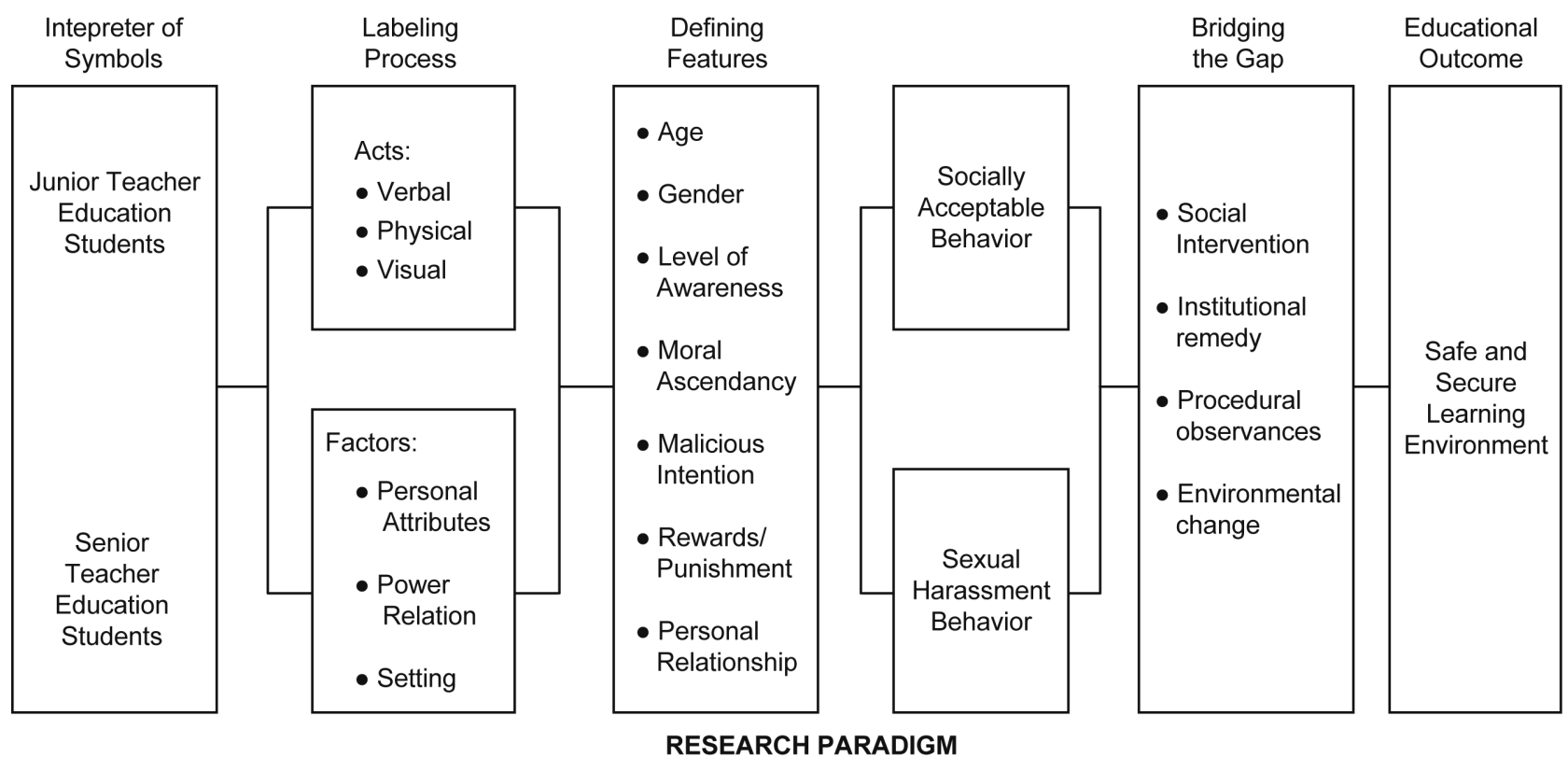

Figure 1. Drawing the demarcation line: Socially acceptable and sexual harassment behaviors. 
The fifth box contains the institutional responses, social intervention or observance of procedures and environmental hygienic agents to delineate the demarcation line between socially acceptable and sexual harassment behavior.

The last box consists of the educational outcomes summarized as safe and secure learning environment which the students rightfully deserve. Figure 1 shows the paradigm, to wit.

\subsection{The Use of Case Study Method}

The case study method was used for two main reasons: 1) the study may serve as a theoretical example of arrangements and processes related to interpretation of sexual harassment behaviors. 2) The Anti Sexual Harassment Law is already existing in almost all countries. The findings of the study may serve as guide to teachers or professionals dealing with education of the young people to recalibrate their interaction with students to prevent unjust accusation of sexual harassment.

\subsection{The Instruments}

The researcher distributed more than 200 survey questionnaires to the four colleges of education in four universities in Nueva Ecija and retrieved $85 \%$ of them. After the trimming phase, he came out with 160 Teacher Education Students as respondents. The description of Junior and Senior Teacher Education students on verbal, visual and physical behaviors are measured by the use of Likert Scale; 1 - 1.66 ("Not" a sexual harassment behavior) 1.67 - 2.33 ("Sometimes" interpreted as sexual harassment behavior) 2.34 - 3.0 ("always" a sexual harassment behavior). The instrument consists of three main parts: The first part pertains to the demographic profile of the respondents; the second part relates to hypothetical scenarios where the respondents would identify whether they are considered as sexual harassment or not. Most of the scenarios on the questionnaires are the result of pre-survey and culled out from the actual scenarios in the narration of victims in selected cases decided by the Philippine Supreme Court. The last part consists of the general knowledge on RA 7877 used as tool to measure level of awareness and understanding of respondents of the law. The data gathered are reinforced by interview and personal observation and Focus Group Discussion (FGD).

\section{Results and Discussion}

\subsection{Demographic Profile of the Respondents}

The demographic profile is presented in Table 1. There were 160 respondents who participated in the study. They are divided into two groups of 80 studentrespondents (senior and junior). The profile of the respondents as to gender is presented below, to wit.

Majority of the respondents are female students. This is not surprising because the College of Education in four universities are female dominated. Majority of senior teacher education students are female while only 10 of the respon- 
dents-senior students are males. It is noteworthy that sexual harassment as an offense is not gender exclusive. In terms of age Table 2 presents the age brackets of the respondents.

The illustration shows that $94 \%$ of the entire sample population belong to age bracket 19 - 20. In the case of junior students, majority of the respondents or $76 \%$ are 18 years old and is capable of giving informed consent to the study. None is of age of minority considering the sensitivity of issue under study.

\subsection{Junior and Senior Teacher Education Students Description of Behaviors}

As Table 3, Table 4 and Table 5 reflected, the majority of junior respondents responded that the three behaviors and actual scenarios posed in the survey questionnaires believe that they are not sexual harassment behaviors. The other significant findings are presented in the succeeding tables to wit.

Table 3 revealed that, 60 Junior Teacher Education students or 75\% consider verbal behaviors presented on questionnaires as sexual harassment behaviors.

Table 1. Respondents profile as to gender.

\begin{tabular}{ccccc}
\hline Gender & Senior & $\%$ & Junior & $\%$ \\
Male & 10 & $12.50 \%$ & 20 & $25 \%$ \\
Female & 70 & $87.50 \%$ & 60 & $75 \%$ \\
Total & 80 & $100 \%$ & 80 & $100 \%$ \\
\hline
\end{tabular}

Table 2. Respondents profile as to age.

\begin{tabular}{ccccc}
\hline Age & Senior & $\%$ & Junior & $\%$ \\
\hline 18 years & 3 & $4 \%$ & 61 & $76 \%$ \\
$19-20$ & 75 & $94 \%$ & 16 & $20 \%$ \\
20 -above & 2 & $2 \%$ & 3 & $4 \%$ \\
Total & 80 & $100 \%$ & 80 & $100 \%$ \\
\hline
\end{tabular}

Table 3. Comparison of descriptions as to verbal behavior.

\begin{tabular}{ccccccc}
\hline Responses/percentage & Not SH & $\%$ & SHB & $\%$ & ASB & $\%$ \\
\hline Juniors & 60 & 75 & 15 & 19 & 5 & 6 \\
Seniors & 38 & 47 & 20 & 25 & 22 & 27 \\
\hline
\end{tabular}

Table 4. Comparison of descriptions as to visual behavior.

\begin{tabular}{ccccccc}
\hline Responses/percentage & NSH & $\%$ & SSB & $\%$ & ASH & $\%$ \\
\hline Juniors & 65 & 85 & 6 & 7.5 & 9 & 11 \\
Seniors & 44 & 55 & 12 & 0.2 & 24 & 30 \\
\hline
\end{tabular}


Table 5. Comparison of descriptions as to physical behavior.

\begin{tabular}{ccccccc}
\hline Responses/percentage & NSH & $\%$ & SHB & $\%$ & ASH & $\%$ \\
\hline Juniors & 59 & 69 & 11 & 14 & 9 & 11 \\
Seniors & 47 & 59 & 13 & 0.2 & 20 & 25 \\
\hline
\end{tabular}

Only $47 \%$ of Senior teacher education students identified and considered the behaviors as verbal sexual harassment. The $25 \%$ of Senior teacher education Students considered the cited behaviors as not sexual harassment behaviors. The result is a little higher than the Junior teacher education students' responses which revealed a measly $19 \%$ saying that those behaviors are not sexual harassment behaviors. Meanwhile, 27\% of senior students revealed that they did not know the nature of the behavior. It is higher than the junior students' perception having only (6) six percent showing that they could not categorize the nature of the behavior as to whether they are considered "Always Sexual Harassment Behavior" (ASHB) or "Not Sexual Harassment Behavior" (NSHB) and Sometimes a Sexual Harassment (SHB) behavior. Table 4 shows, the description/categorization of Senior and Junior Teacher Education students on certain visual behaviors as sexual harassment or not. The result shows that $65 \%$ of 80 Junior students claimed that item-behaviors fall under sexual harassment behaviors while only $44 \%$ of the Senior teacher education students described the behaviors as sexual harassment. Six percent of Junior students claimed that they do not consider the presented acts as sexual harassment behavior while $12 \%$ of the Senior student-respondents asserted that they are not sexual harassment behaviors Finally, $30 \%$ out 80 Senior students-respondents claimed that they did not know whether they are sexual harassment behaviors or not. Respondents considered the behaviors presented as sexual harassment behaviors while 59\% percent of Senior student respondents claimed that presented behaviors are sexual harassment. Only $11 \%$ of Juniors and $13 \%$ of Senior student respondents respectively perceived that they are not falling under physical sexual harassment behaviors. Finally, $11 \%$ of Junior student-respondents and $25 \%$ of Senior student-respondents did not know the nature of the behaviors.

\subsection{Interpretation of Junior and Senior Teacher Education Students on Sexual Harassment Behaviors}

\subsubsection{Verbal Behaviors}

Among the junior teacher education students, sexist language is a verbal act interpreted as sexual harassment. The items that have the highest Weighted Mean (WM) are those with sexual terms such as "big breasts" and "good in bed" respectively are terms with derogatory and offensive connotations. The weighted means of 2.56 and 2.31 were derived. Meantime, the perception of senior teacher education students, has and the highest weighted mean among verbal behaviors, are spreading sexual rumors and having a big breasts with 2.78 and 2.77 mean scores respectively. Table 6 of weighted mean scores is presented hereto. 
Table 6. Summary table of general weighted means for three behaviors on the perspectives of junior and senior teachers education.

\begin{tabular}{ccc}
\hline Type of Behaviors & Junior & Senior \\
\hline 1) Verbal Behaviors & 2.23 "Sometimes" & 2.76 "Always" \\
2) Visual Behaviors & 1.95 Sometimes" & 2.24 Sometimes" \\
3) Physical Behaviors & 2.4 "Always" & 2.64 "Always" \\
\hline
\end{tabular}

\subsubsection{Visual Behavior}

Meanwhile, from the responses of teacher education students on visual behaviors has the highest weighted mean computed as 2.38 which pertains to the item "teacher exposure of sensitive parts of his body". It seems that senior teacher education students considered "exposure of sensitive parts" as visual sexual harassment behavior regardless of whether or not malicious intention is present Also, the overall weighted mean of 2.24 was derived from the responses of the Junior teacher education students. Among the presented visual behaviors in the questionnaires, "showing of sensitive body parts" has the highest weighted mean. This implies that the same act has the highest consideration as a sexual harassment act on the point of view of the Junior teacher education students. The same item was also given the highest consideration by the Senior teacher education students as a sexual harassment act regardless of the absence or presence of malicious intention.

\subsubsection{Physical Behaviors}

The "exposure of the body parts" has the highest mean score of 2.38 which is verbally described as "sexual harassment behavior". The respondents do not qualify whether with or without malicious intent. The table also showed that Junior teacher education students treated the behaviors as physical sexual harassment behaviors. In fact, it has an overall mean score of 2.68 verbally interpreted as "always". The result means that the respondents would give meaning to the cited acts as sexual harassment acts. Among the cited physical behaviors, it is "forced sitting on the lap of student" is given the highest mean score of 2.8 verbally interpreted as always. It is noteworthy that among the behaviors cited; visual, sexual and physical; it is physical behavior that easily convinced the respondents that the person committing it has malicious intention to commit sexual harassment. Among the presented scenarios it is with "physical behaviors" insinuating sexual request considered sexual harassment to both groups of respondents to wit; The general weighted mean scores of 2.24 and 2.65 respectively for junior and senior groups of teacher education students showed their commonality in the interpretation. It can be deduced that any sexual request coupled with physical behavior/actions is always interpreted by the respondents as sexual harassment behavior. On the other hand, the responses are diverse in the interpretation of verbal behaviors as shown by weighted mean scores of 2.23 and 2.76 verbally interpreted as "sometimes" and "always". On this note senior teacher education students tend to interpret verbal behaviors as sexual harassment more 
than junior students. Finally, both groups consider visual behaviors presented as "sometimes "interpreted as falling under sexual harassment behaviors.

\section{Demarcation Line between Sexual Harassment and Socially Acceptable Behaviors on the Point of View of Teacher Education Students}

Table 7 that follows presents the demarcation line when an act otherwise socially acceptable qualifies as sexual harassment behavior using as parameter senior and junior teacher education student's perspectives, to wit.

\subsection{Promise of Rewards}

Students considered an invitation for a date a sexual harassment when it involves reward or punishment. In case approval of the invitation would help the students complete or receive a passing grade in exchange for a date.

\subsection{Relationship}

Friendship between faculty members and female students is a common thing. Any touching not on the sensitive parts of the body, is not interpreted as sexual harassment behavior considering when they are friends and those should not be given malicious interpretation.

Table 7. Demarcation line and sexual harassment behaviors.

\begin{tabular}{|c|c|c|c|}
\hline Behaviors & Acceptable if & Demarcation Line & Sexual Harassment if \\
\hline 1) Asking for a date & Without R\&P & Reward/punishment & $\begin{array}{c}\text { With Promise } \\
\text { of R\& P }\end{array}$ \\
\hline 2) Touching & Friends & Friendly Relation & $\begin{array}{l}\text { Without } \\
\text { relationship }\end{array}$ \\
\hline 3) Invitation for a date & Non graduating & Senior standing & If graduating \\
\hline 4) Touching of body & For Male & Gender & If woman tends to \\
\hline 5) Commission of acts & In Public & $\begin{array}{l}\text { Place when } \\
\text { committed }\end{array}$ & $\begin{array}{l}\text { If in private and } \\
\text { in isolation }\end{array}$ \\
\hline 6) Sexual invitation & Not repetitive & Insistence/demands & $\begin{array}{l}\text { If there is } \\
\text { repetition/insistence }\end{array}$ \\
\hline 7) Invitation for a date & With consent & Consent & If without consent \\
\hline 8) Person inviting & Pleasing & Personality & $\begin{array}{c}\text { If without pleasing } \\
\text { personality }\end{array}$ \\
\hline 9) Invitation/material gain & $\begin{array}{c}\text { If male } \\
\text { interpreter }\end{array}$ & $\begin{array}{l}\text { Material gains } \\
\text { and Gender }\end{array}$ & Female interpreter \\
\hline 10) Sexual invitation & Male & Gender & $\begin{array}{c}\text { Female tends to } \\
\text { label as such }\end{array}$ \\
\hline
\end{tabular}




\subsection{Stage or Year Level of the Students}

Graduating students tend to interpret any of the sexual, visual or physical behavior as sexual harassment act. This is based on their belief that due to their status they are prone to sexual harassment.

\subsection{Male Students Tend to Strictly Interpret Sexual Harassment Behavior}

Male students tend to label their action as sexual harassment only when there is already a body contact or actual sexual congress especially during "drinking spree" with their teacher who is a member of the third sex. Intentional body touching is not sexual harassment especially when done during drinking spree or festive occasion.

\subsection{Place When Act Is Committed}

Many of the respondents consider the place a qualifying circumstance. When it is committed alone with the harasser they considered it as sexual harassment. When the same is committed in front of others, they consider it as a mere joke synonymous to a teacher verbalizing sexist language in the middle of the classroom discussion.

\subsection{Insistence of Harasser}

The respondents consider the act as sexual harassment when the harasser is insistent on the demand for sexual favor.

\subsection{The Presence of Consent}

When demand for a date or sexual favor is rejected the act is a sexual harassment. But when the victim acceded to the demand, they did not consider it as a sexual harassment but a consensual relationship. There is a wrong notion that consent is a waiver of their right to file a complaint against sexual offender.

\subsection{Physical Appearance of Harasser}

When the harasser is having displeasing personality (ugly) they tend to interpret the behavior as harassment. But when of pleasing personality, they tend to label the act as consensual.

\subsection{Presence of Material Benefits}

Many male respondents tend to label physical acts of teachers who are homosexual as harassment when there is no material gain. However, especially when it involves grades or during "Gimmick" which the faculty sponsored, no sexual harassment is interpreted.

\subsection{Gender}

Female students consider sexual acts more often as sexual harassment behaviors than males. They said that by the nature of their gender, they expect higher level 
of respect from their teacher. Thus, if sexual harassment behavior (verbal) is committed by their teacher they tend to think that those are meant

\section{Teacher Education Junior and Senior Students Description of Their Level of Awareness on RA 7877}

Table 8 shows the level of awareness of Senior Teacher education students on RA 7877. The overall weighted mean of scores is 2.12 verbally interpreted as median range. This could be interpreted to mean that Senior teacher education students level of awareness is neither high nor low.

That their basic knowledge of sexual harassment in so far as elements, rules and regulation and some of the consequences are concerned, are neither aware nor unaware of their existence. Table 8 shows that $38 \%$ of the respondents Senior teacher education students awareness of the basic requisites for the application of RA $7877.31 \%$ or 25 of the respondents do not possess basic knowledge or legal requisites to apply the law. Finally, 24 of the respondents out of 80 or $30 \%$ opted not to answer the questions. Table 8 shows the Junior teacher education students level of awareness on RA 7877. There are 42 of the respondents or equivalent to $52 \%$ out of eighty 80 respondents aware of the elements of sexual harassments are presented. Twenty two (22) out of eighty (80) respondents' equivalent to $27 \%$ of them do not have the basic knowledge of the requisites for the application of RA 7877. Finally, 16 of the respondents out of 80 or $20 \%$ of them opted not to answer the questions. Table 8 also shows that respondents Junior teacher education students are aware of the elements, requisites, nature

Table 8. Junior and senior teacher education students description of their level of awareness.

\begin{tabular}{|c|c|c|c|c|c|c|c|c|c|c|c|c|c|c|}
\hline Basic Knowledge on Sexual Harassment & & & & unios & & & & & & & Senio & & & \\
\hline $\begin{array}{c}\mathrm{N}=\text { Not sexual harassment, } \mathrm{NA}=\text { No answer, } \\
\mathrm{WM}=\text { Weighted Mean }\end{array}$ & $\mathrm{Y}$ & $\mathrm{TF}$ & $\mathrm{N}$ & $\mathrm{TF}$ & $\mathrm{N}$ & TF & WM & Y & $\mathrm{TF}$ & $\mathrm{N}$ & $\mathrm{TF}$ & NA & $\mathrm{TF}$ & WM \\
\hline $\begin{array}{l}\text { 1) Sexual harassment involves sexual favor in } \\
\text { exchange for something or favor }\end{array}$ & 56 & 168 & 9 & 18 & 14 & 14 & 2.5 & 33 & 99 & 24 & 48 & 23 & 23 & 2.12 \\
\hline $\begin{array}{l}\text { 2) Sexual harassment requires subordinate-superior } \\
\text { relationship }\end{array}$ & 26 & 78 & 26 & 52 & 24 & 24 & 1.92 & 21 & 63 & 37 & 74 & 22 & 22 & 1.98 \\
\hline $\begin{array}{l}\text { 3) I know the person to talk to in case I feel that } \\
\text { I am sexually harassed }\end{array}$ & 28 & 84 & 48 & 96 & 4 & 4 & 2.3 & 34 & 102 & 13 & 26 & 33 & 33 & 2.01 \\
\hline $\begin{array}{l}\text { 4) I believe that any sexual harassment case must be } \\
\text { reported to proper to the proper school authorities }\end{array}$ & 54 & 162 & 16 & 32 & 10 & 10 & 2.55 & 30 & 90 & 23 & 26 & 27 & 27 & 1.78 \\
\hline $\begin{array}{l}\text { 5) I believe that reporting the matter to the proper } \\
\text { university official, the person who harassed me will } \\
\text { be penalized }\end{array}$ & 48 & 144 & 9 & 18 & 23 & 23 & 2.31 & 41 & 123 & 24 & 48 & 15 & 15 & 2.32 \\
\hline $\begin{array}{l}\text { 6) The fact of my reporting to proper authority } \\
\text { would adversely affect my academic standing }\end{array}$ & 38 & 114 & 24 & 48 & 18 & 18 & 2.25 & 26 & 78 & 27 & 54 & 27 & 27 & 1.98 \\
\hline Overall Weighted Mean: & 42 & 126 & 22 & 44 & 16 & 16 & 2.32 & 31 & 93 & 25 & 50 & 24 & 24 & 2.12 \\
\hline
\end{tabular}


and consequences of sexual harassment or RA 7877. It is supported by an overall mean score of 2.32 verbally described as "consider acts as sexual harassment acts". In other words they are "aware" of the contents of Anti-Sexual Harassment Act or 7877. It is the presence of "subordinate-superior relationship" that qualifies the act as sexual harassment act has the lowest mean score of 1.92 verbally described may or may not "as sexual harassment act. This goes to show that in their minds, there is a possibility that they would consider an act as sexual harassment even without the superior-subordinate relationship as they are not certain of the need to have the relationship exists before a case qualifies as a sexual harassment case.

It is respectfully submitted that this pinch of uncertainty would expose the faculty and even classmates of the respondents to be charged of sexual harassment act even if the act is more accurately define as a simple case of irritation but not sexual harassment punishable under the Revised Penal Code provisions and not by RA 7877 .

\section{Significant Difference between the Junior and Senior Teacher Education Students Responses across Universities}

The data below show the statistical evidence to accept the null hypothesis. As observed, there is no significant difference between the levels of awareness on sexual harassment act on the part of the two group samples. The test result is presented below.

\section{Testing of Hypothesis:}

The t-test result of the significant difference between the responses of senior and junior teacher education students on sexual harassment.

\begin{tabular}{ccc}
\hline & Junior & Senior \\
\hline Mean & 2.43 & 2.23 \\
Sd & 0.37 & 0.07 \\
Df & 0.6 & \\
Computed t & 1.936 & \\
Tabulated t & 2.447, two tailed, 5\% & \\
Decision & Accept Ho & \\
Interpretation & Not significant
\end{tabular}

Since the computed $t$ value of 1.936 is less than the tabulated $t$ value of 2.447, there is enough statistical evidence to accept the null hypotheses; hence it can be concluded that there is no significant difference between the responses of Senior and Junior teacher education students on sexual harassment. At 5\% level of significance, the mean response of the junior teacher education students is not significantly higher than the mean response of senior teacher education students. 
The study showed the diverse interpretation of respondents on potential sexual harassment acts. It also showed the need to increase level of awareness on sexual harassment. Towards the goal of preventing sexual harassment in learning institution, there is a need to reorient society on the issue using sociocultural and power approaches in the analysis of sexual harassment. A nationwide study on the issue to level of and lay down theoretical guidelines on teachers' behaviors potentially interpreted as sexual harassment behavior of students is necessary. The government must ensure that dissemination, implementation and observance of organizational guidelines on teacher's behavior are observed. There are defining features of sexual harassment behaviors which teachers must bear in mind to evade undue accusation of sexual harassment. As the study pointed out, the symbolic interactionism as a theoretical model implies that the same gesture may create different meanings to different persons. Sexual harassment is greatly dependent on the perception of victims and their meaningful interpretation. Although, the study is not done in a laboratory setting, the emergence of results may contribute to the prevention measure which private and government institutions may design and use as a set of standard of behavior within a learning institution. Learning institution is not only a provider of quality education to young people. It has also the duty to maintain safe and peaceful environment for the students and faculty members.

\section{Acknowledgements}

Thank you very much for the cooperation of the participants of the four universities; Nueva Ecija University of Science and Technology, Wesleyan-University Philippines, Phinma-education Network in Cabanatuan City and Central Luzon State University in the Science City of Munoz, Nueva Ecija.

\section{References}

[1] Mackin, N.C. (1981) Review of Sexual Harassment of Working Women. https://www.google.com.ph/webhp? sourceid=chrome-instant\&ion=1\&espv=2\&ie= UTF-8\#q=review\%20of\%20sexual\%20harassment\%20of\%20working\%20wo

[2] Vohlidalova, M. (2011) The Perception and Construction of Sexual Harassment. Wellesley Centers for Women, Wellesely College Stone Center. http://www.soc.cas.cz/en/publication/perception-and-construction-sexual-harassme nt-university-students-case-czech-republic

[3] American Equal Employment Opportunities. https://www.eeoc.gov/laws/types/sexual_harassment.cfm

[4] Samonte, E. (1995) Sexual Harassment: Perceptions of UP Students and Faculty. Review of Womens' Studies, 3, 101-145.

[5] Cortina, L.M. and Berdahl, J.L. (2008) Sexual Harassment: A Decade of Research in Review. http://sk.sagepub.com/reference/hdbk_orgbehavior1/n26.xml

[6] Baludi, M. (1996) Sexual Harassment on College Campuses: Abusing the Ivory Tower. State University of New York. www.sunypress.edu/p-2280-sexual-harassment-on-college-ca.aspx

[7] Wolowelsky, J.B. (1989) Reducing Grades as a Means of Imposing Discipline. 
http://www.lookstein.org/articles/grades_discipline.htm

[8] Uggen, C. and Blackstone, A. (2004) Sexual Harassment as a Gendered Expression of Power. American Sociological Review, 69, 64-92.

https://doi.org/10.1177/000312240406900105

[9] Congress of the Philippines RA 232-Education Act of 1982. www.lawphil.net/statutes/bataspam/bp1982/bp_232_1982.html

[10] Gabriel, A.G. and Mangahas, T.L. (2016) Revisiting the Anti-Hazing Law in Selected Higher Education Institutions in Nueva Ecija, Philippines: A Policy Review. Open Access Library Journal, 3, e3177. https://doi.org/10.4236/oalib.1103177

[11] Gabriel, A. and Gabriel, J. (2016) Basic Education Teachers and Workplace Bullying in the Philippines: An Organizational Prism. Imperial Journal of Interdisciplinary Research, 2, 2150-2156. http://www.onlinejournal.in

[12] Smit, D. and du Plessis, V. (2011) Sexual Harassment in the Philippines Education Sector. http://www.nwu.ac.za/webfm_send/42525

[13] Valls, R. (2016) Breaking the Silence at Spanish Universities. Findings From the First Study of Violence Against Women on Campuses in Spain. https://www.ncbi.nlm.nih.gov/pubmed/26825116

[14] Kamal, K. and Asrulkhadi, A. (2011) Is It a Case of Gendered Perspective? International Journal of Humanities and Social Science, 1, 295-301.

[15] Hill, G. and Kearl, H. (2011) Crossing the Line: Sexual Harassment at School. American Association of University Women. http://www.aauw.org/research/crossing-the-line/

[16] Bernas, J. (2008) An Introduction to Public International Law. Rex Bookstore, Manila.

[17] The 1987 Philippine Constitution Official Gazette of the Republic of the Philippines. http://www.gov.ph/constitutions/1987-constitution/

[18] Philippine Congress the Labor Code of the Philippines PD774 Official Gazette of the Republic of the Philippines. http://www.gov.ph/constitutions/1987-constitution/

[19] Philippine Development Plan 2011-2016 Results Matrices. www.neda.gov.ph/wp-content/uploads/2013/10/pdprm2011-2016.pdf

[20] RA 7877. An Act Declaring Sexual Harassment Unlawful in the Employment, Education or Training Environment, and for Other Purposes.

http://pcw.gov.ph/law/republic-act-7877

[21] Philippine Commission on Women (2013).

[22] Philippine Civil Service Commission (CSC) Administrative Disciplinary Rules on Sexual Harassment. http://www.chanrobles.com/republicactno7877rules.htm

[23] Kintanar, T. (2000) Review of Women Studies. 20-32.

[24] Akhtar, C. (2013) Sexual Harassment at Workplace and in Educational Institutions: A Case Study of District Srinagar, Kashmir. International NGO Journal, 8, 54-60. https://doi.org/10.5897/INGOJ2013.0265

[25] Blumer, H. (1969) Symbolic Interactionism. https://www.utwente.nl/cw/theorieenoverzicht/Theory\%20Clusters/Interpersonal\% 20Communication\%20and\%20Relations/Symbolic_Interactionism/ 
Submit or recommend next manuscript to OALib Journal and we will provide best service for you:

- Publication frequency: Monthly

- 9 subject areas of science, technology and medicine

- Fair and rigorous peer-review system

- Fast publication process

- Article promotion in various social networking sites (LinkedIn, Facebook, Twitter, etc.)

- Maximum dissemination of your research work

Submit Your Paper Online: Click Here to Submit

Or Contact service@oalib.com 